\title{
Dying a Good Death: Indonesian Rituals and Negotiations About the End of Life
}

\author{
Claudia Seise | ORCID: 0000-0001-6234-2813 \\ PostDoc Fellow Berlin Institute of Islamic Theology, \\ Humboldt University of Berlin, Germany \\ claudia@seise.de; claudia.seise@hu-berlin.de
}

\begin{abstract}
In the following article, I aim to provide an insight into the Islamic understanding of death as perceived by a typical Indonesian Muslim family in South Sumatra. The discussion on what it means to die a good death is used as a central theme to introduce the Islamic rituals and practices surrounding death. I pay special attention to the signs observed by the members of the family while accompanying the dying person and examine how these are grounded in the particular religioscape of South Sumatra. The article is written at the crossroad of area studies and Islamic theology.
\end{abstract}

\section{Keywords}

Death in Islam - Indonesian Islam - death rituals - religioscape - South Sumatra - Indonesia

When I received the news that my father had passed away, I supplicated (berdoa) to Allah to please make it just suspended animation (mati suri). However, when they brought my father's body home and I saw his face, I withdrew my supplication (doa) and was pleased (ikhlas) with my father's death. (Maryam)

1 The open access option for this article is funded by the Federal Ministry of Education and Research of Germany as part of the project 'Establishment of the Berlin Institute for Islamic Theology'. I thank the two anonymous reviewers for their valuable feedback.

(C) CLAUDIA SEISE, $2021 \mid$ DOI:10.1163/25899996-BJA10014

This is an open access article distributed under the terms of the CG BY 4 o license. Brill, com04/25/2023 11:51:39PM 
Discussions on funeral rituals and practices surrounding death in Indonesia have focused on different death rituals from different places and traditions in the archipelago, including death rituals from the people of Tana Toraja (Adams, 1993; Grillo 2008), the Ngada in Central Flores (Schröter, 1998), collective burial practices in different parts of Indonesia (Schmitt et al., 2018), cremation rituals in Bali (Rajendra \& Temple, 2016), and death rituals from the Pide community in Aceh (Abdul Manan, 2015; Abdul Manan \& Arifin 2019). Different selected rituals like the Muslim communal feast of slametan have been discussed at length (Geertz, 196o; Hefner, 1985; Woodward, Bowen 1993; 2011; van den Bookgert, 2017; Nasir, 2019). ${ }^{2}$ However, it appears that perceptions and rituals surrounding the end of life as observed by the Muslim majority in Indonesia have only received minor attention (for Pidie, Aceh see Abdul Manan, 2015). In Muslims through Discourse, Bowen (1993) paid attention to tensions about the permissibility of traditional rituals including those related to death in Gayo society in Sumatra. Samuels (2019) discusses the ethical processes of grieving in post-Tsunami Aceh. Looking outside of Indonesia, there exist several studies related to death and Islam, including Choong (2015) on palliative care and Rinker (2020) on "actively dying" and the creation, transformation, and contestation of Muslim identities and religiosity within the social, economic, and political context of the United States. Understanding how a good death is perceived and the signs that accompany it seems not to have been a matter of research. This study is meant to be a meaningful addition that will hopefully inspire more research in this particular area of study.

In this article I aim to provide an insight into the way in which the Islamic worldview of an Indonesian Muslim family in South Sumatra is reflected in their specific approach towards death. Field research for this article was undertaken in South Sumatra from August until October 2019 during a one-year research stay in South Sumatra, Indonesia. I am related to the family through my husband. The permission to write about my father-in-law's death has been given. However, to protect my husband's family, I have changed names and places. The discussion about the perception of a good death and what it means to die

2 Geertz (1960) remarked that at the center of the whole Javanese religious system lies a simple, formal, undramatic, and almost furtive little ritual: the slametan, the Javanese version of what is perhaps the world's most common religious ritual: the communal feast. The slametan has played an important role in Javanese Islam. Geertz regards slametan as an abangan ritual, whereas Woodward views it as justified by Islamic texts. Woodward argues, "The religious goals of the slametan are rooted in local interpretations of the Sufi theory of mystical union, and the modes of ritual action it employs are based on practices attributed to the Prophet Muhammad (Hadith)" (Woodward 1989: 52, In: Ali, 2011).

I view the $s(e)$ lametan similar to Woodward. 
a good death will serve as a red thread when introducing traditional rituals and practices. Here, I will pay special attention to the signs observed by the members of the family while accompanying the dying person. The interpretation of these signs is of vital importance to understand what it means for Indonesian Muslims to die a good death. Several of the signs discussed here are mentioned in classical Islamic texts, and I will make reference to them where appropriate. Before going into the details of my case study, I will introduce the traditional religioscape of South Sumatra and then provide a short overview of death according to the Islamic worldview. Here I rely heavily on my own learning and my own experience with the Islamic tradition, especially as understood and lived by Muslims in Indonesia. Since the Qur'anic chapter Yasin features heavily in the discussion about death in Islam, I will provide a short overview of this Surah and its application among Muslims. Following, besides discussing the signs observed in the dying person, I will also pay close attention to the rituals observed and conducted after death. These rituals reflect the family's location within the religioscape of South Sumatra, meaning that they reflect the family's grounding in what is usually referred to as traditional Islam or traditional Islamic practices. Observing these rituals causes ruptures in the 'religious periphery' of the village (kampung) where a new religioscape developed that is different to the traditional one. The kampung under study is home to a small but growing number of adherents to a strict Wahhabi interpretation of Islam, which means that some members openly refuse to participate in the traditional rituals following the death of the household head. This conflict is topic of the last part of this article where I argue that post-mortem rituals and good care for the deceased can be viewed as being part of understanding the perception about a good death. The rupture around the Yasinan ritual illustrates that what is considered 'Islamically good' ritual post-mortem care is disputed.

Trained in area studies, I work with qualitative research methods, including participatory observations, semi-structured and open interviews, and situational analysis (Clarke, 2005) that can be described as an ethnographically founded research paradigm of New Area Studies (Baumann, 2020). In this respect, thick description is an essential part of communicating my research findings. The way I read my data is both rooted in my training in area studies at the Humboldt University of Berlin as well as an attempt to include Islamic theology in my framework of analysis due to my own Muslim identity (Seise, 2019). Islamic theology in this context is derived from the German term Islamische Theologie, which comprises a new field established at different centers of Islamic theology at German universities. Different to Islamic studies (Islamwissenschaften), Islamic theology in Germany aims to provide an emic perspective that intends to set itself apart from Islamic and Oriental 
studies that cannot be separated from colonial history. In addition, writing from within Islamic theology allows for explicit expressions of an Islamic worldview that include references to the Qur'an, the Sunnah, and Muslim scholars from diverse Islamic traditions, as well as normative statements of religious reality and belief.

\section{$\mathbf{2}$ The Religioscape of South Sumatra}

Religioscapes are dynamic social spaces where one religious practice or interpretation is predominant. Religioscapes are neither purely static nor entirely fluid. Cultivated historically, they include movement, change, and transformation, as well as continuity and stability of religious practices and interpretations. Religioscapes are influenced by individuals and influence individuals. This constitutes a mutual process. Religioscapes can extend and shrink depending on the individuals' preference, influence and connections within it. Different religioscapes can exist within one geographical region and several religioscapes can overlap. Religioscapes allow for an analysis and understanding about relations and dynamics between different spatial scales ranging from the local to the global (Seise, 2017:30-31). Historically, the religioscape of South Sumatra, especially its provincial capital Palembang, consisted of three different teachings of Islam. Firstly, Shattariyyah teachings similar to those found in Java and which were later replaced by the second teachings. Those consisted of the Sammaniyah tarekat and what Azra (2004) describes as neo-Sufism that places a stronger emphasis on the observance of the shariah. These teachings, which included the thought of scholars like al-Palembani (probably died 1789), and teachings that were largely based on the perspectives of al-Junayd (died 909/10), al-Qushayri (986-1072) and al-Ghazali (1058-1111), were sponsored by the Palembang Sultanate in the 18th century (Azra, 2004). It was Abdul Samad al-Palembani who, along with Arshad al-Banjari (died 1812) "played a crucial role in pointing Malay courts towards the writings of al-Ghazali and his Egyptian interpreters" (Laffan, 2011: 28). Translations of al-Ghazali's work into the Malay language, which were not the initial exposure but illustrate a greater intensification with his works, started in the 17th century (Moris, 2016: 8). Here, al-Palembani played an essential, if not the, essential role in spreading al-Ghazali's teachings in the Malay speaking world. ${ }^{3}$ The third teaching of

3 Moris (2016) argues that al-Ghazali's influence was also clear on the Walisongo, the nine legendary saints who are believed to have spread Islam in Java starting from the 14th century CE. One of the Walisongo, Sunan Bonan (probably died 1525), in the treatise wirasanin usul suluk attributed to him, gathered his arguments mainly from al-Ghazali's Ihya (ibid: 37 ). 
Islam found in the religioscape of South Sumatra is the set of teachings and practices brought by Hadhrami migrants (Alawiyin) starting from the middle of the 18th century. Until today, the Islamic practices and teachings observed by the progeny of the Alawiyin are very similar to the Islamic practices found in contemporary Yemen. These include annual Islamic festivities like the Maulid or Ziarah (Alatas, 2008, 2014, 2016) as well as personal Islamic practices like dzikir and social practices like the strict separation of men and women and a gendered division of the public and domestic domain (Slama, 2012). It is important to note that Hadhrami migrants played an "important role in the growth of the tradition of Islamic learning in the region" (Azra, 2004: 112), and "encouraged the Sultans of Palembang to pay special attention to religious matters" (ibid). In addition, nowadays there exist other religioscapes in the area of South Sumatra as will be illustrated with the example of negotiating the ritual of Yasinan in the last part of this article.

When discussing the Islamic worldview of death among the members of a traditional Indonesian family in South Sumatra, some of the points mentioned above are of special importance. First of all, the works of Imam al-Ghazali and his influence on the Palembang court, which consequently spread to the common Muslim people. Second, the influence of Islamic rituals brought to South Sumatra by the descendants of Hadhrami migrants. Several of my informants in Palembang claimed that the reading of Surah Yasin for the first seven days after the death of a Muslim and continuing on the 4oth, 10oth and 1,oooth day was a practice introduced by the descendants of the Prophet Muhammad. ${ }^{4}$ Reading the works of al-Ghazali or commentaries on it, including al-Palembanis's works, is an important feature of traditional Islam in Indonesia. The Nahdlatul Ulama count the tasawwuf method devised by al-Ghazali and Junayd al-Baghdadi as one part of what constitutes the religion of the ahl al-sunnah wal-jamaiah. Both integrate tasawwuf, the science of Islamic spirituality, with the shariah. Van Bruinessen (1990), writes in his study of the Kitab Kuning (Yellow Books) taught in traditional Indonesian pesantren (Islamic boarding schools) that the section on tasawwuf is strongly dominated by al-Ghazali and his Ihya 'ulum al-din, Bidayah al-hidayah and Minhaj al-abidin. There are various pesantren and study circles (pengajian) around Indonesia and also South Sumatra that

4 It is especially these rituals that are strongly criticized among so-called reformist Islamic groups, including the Muhammadiyah and different Salafi-Wahhabi groups. Their argument is that they reflect pre-Islamic practices from the times when Indonesia's majority population was still Hindu or Buddhist. However, my informants in Palembang argue that these rituals are part of the Hadhrami Islamic tradition. The argument for a pre-Islamic, syncretic origin of these rituals is also made by many scholars writing about the Javanese slametan. They argue in favor of an acculturation of pre-Islamic rituals into the Islamic framework (Geertz 1960; van den Boogert, 2017; Manan \& Arifin, 2019; Nasir 2019). 
specialize in the teaching of the Ihya. All three works authored by al-Ghazali have been translated, at least in part, into several Indonesian languages and are commercially quite successful. "Quietist, orthodox Sufism apparently has a wide appeal beyond the pesantren milieu as well - which seems to be a response to the political decline of Indonesian Islam over the past decades" (van Bruinessen, 1990: 260).

\section{3}

\section{Death in the Islamic Worldview}

The traditional Islamic worldview is usually understood to be a very balanced worldview (e.g. Ali, 2017). ${ }^{5}$ This also applies to the connection between present, past and future and how these relate to the perception of and preparation for death. Following, I will describe the Islamic worldview about death as it relates to the Islamic worldview of the Indonesian Muslim family in South Sumatra that is the focus of my case study. Muslims believe that this world is only a transitory stage in a sequence of different stages of life. It is believed that this earthly life was preceded by life in the world of souls (alam arwah) and will be continued by the life in the grave (kubur) when the soul will live in a world in-between (alam barzakh). God will resurrect all humans from their graves to stand before Him on the Day of Judgement, which is said to last for 40.000 years. Then every person will be assigned to either paradise or hell, and both worlds are believed to be the final and eternal abode for all human souls. In this sense, it is believed that all humans are essentially and primarily spiritual beings who have to live as physical beings in this world as a test from God. It is essential to understand these five stages of human existence in order to fully grasp the meaning of death in the Islamic worldview.

Death is seen as a transitional phase that a person has to pass through in order to reach the next level of existence. It is essential to understand that Muslims regard their life in this world is as a test. God sends the human soul to this earth in order to test her. Taking this belief into account, death is considered the end of the earthly test assigned by God. Death, therefore, has the potential to indicate whether a person has passed the test of this world successfully or not. It is thus that Muslim scholars have compiled writings on the

5 Balanced here refers to Islam being a moderate way of life that rejects extremism. Furthermore, balanced refers to God's creation which is in perfect balance and control, and to a balanced Islamic theology ('aqidah), worship ('ibadah), morality, shariah, and a balance between the worldly life and the life after death. 
signs of a good ending (husn al-khatimah) and the signs that point to a bad or evil ending (su al-khatimah).

Taking the above into account, we can understand that death in the Islamic worldview is something a person needs to prepare for. This preparation is especially concerned with passing the test of life successfully in order to be granted paradise in the afterlife. A Muslim should prepare for the future now, take lessons for the present and the future from the past, and have hope for the future. It can be said that the most important point in a Muslim's life is death: once the angel of death is visible to the dying, there is no going back and no possibility for repentance anymore. Seeing good signs during a person's passing over to the next stage of existence is especially important for the family members left behind who take consolation in calling good signs observed to memory. Different to people living in Western countries for example, who console themselves that now the person is free from suffering and probably in a better place, Muslims remind each other and take comfort in the good signs observed in the dying person, which will be described in the next part of this article from the case study of Ahmed's father in South Sumatra.

The classical Islamic scholar Ahmed al-Ghazali described the signs of a good death and a bad death in his book Kitab dhikr al-mawt wa ma ba'dahu (Book of the Remembrance of Death and the Afterlife), the 4oth book in his magnus opus Ihya 'ulum al-din (Revival of the Religious Sciences). According to my own observations, part of these descriptions are known to Muslims in Indonesia and form their understanding of death and the need for preparing for a good death. The reason for this can be found in the unique religioscape of South Sumatra shortly described above where the works of al-Ghazali play a prominent role. Below I quote him directly from an English translation in order to provide the reader with a small insight of how al-Ghazali's work and his words might affect the reader or the person hearing his teaching in a pengajian (religious lecture). Al-Ghazali (from the translation by T.J. Winter, 2015: 47-48) wrote:

Know that it is desirable for the dying man to have an aspect of peacefulness and tranquility. He should be uttering the Two Testimonies [of faith] with his tongue, and should be maintaining in his heart a favourable opinion of God (Exalted is He!). For it is related that the Prophet (may God bless him and grant him peace) once said, 'Watch for three signs in the dying man. If his forehead sweats, his eyes shed tears and his lips become dry, then the mercy of God (Exalted is He!) has alighted upon him. [...]' It is a favourable sign that his tongue should be pronouncing the words of the Testimony. 
Surah Yasin plays a profound role in rituals surrounding death in Indonesia. It is the 36 th chapter of the Qur'an, and across the Muslim world it is probably one of the best known and most recited chapters of the Qur'an, besides the opening Surah al-Fatihah. It plays a very important role in traditional Islamic piety and several Muslim scholars refer to it as 'the heart of the Qur'an', usually citing a well-known hadith: "Everything has a heart, and the heart of the Qur'an is Yasin. Whoever recites Yasin, God records for him the recitation of the Qur'an ten times for his recitation of it”. Furthermore, many Muslims recite Surah Yasin regularly as part of their supererogatory devotions, and it is often the only longer chapter of the Qur'an that Muslims have memorized in full. A famous hadith also recommends to recite Surah Yasin over the dead, and it is thus recited for those who are close to death, those who have just died, and at the grave of loved ones, family, friends or teachers. It is also recited for those who are sick. This practice is based on the hadith: "Verily in the Qur'an there is a Surah that intercedes through its recitation and forgives through its being heard - indeed, that is Surah Yasin". Furthermore, Surah Yasin is also recited by many Muslims after the ritual five daily prayers, especially after the morning and the evening prayer (Nasr, 2005: 1069-1071).

In Indonesia, Surah Yasin is traditionally recited in communion on Thursday night (malam jumat), it is recited for the sick, for the dying, and for the dead. It is read before a marriage takes place, when moving into a new home, to scare an unknown thief into returning stolen goods, and for the dead in their graves when undertaking ziarah. This is also true for many Indonesian Muslims living abroad. During my long term participatory observations in the Indonesian Muslim community in Berlin, I have witnessed several times that people gather together to read Surah Yasin for a deceased family member. When a member of the Indonesian Muslim community falls ill, people take turns to visit him/ her at home or in the hospital to read Surah Yasin and supplicate for him/her. Many Muslims in South Sumatra have also memorized this Surah, and I have witnessed several incidents firsthand that illustrate this fact beautifully where local Muslim women recited Surah Yasin when confronted with challenging situations. The memorization of Surah Yasin points to a complete embodiment of this part of the Qur'an (Ware, 2014) and therefore can be applied in any situation where it is deemed necessary. Concerning the memorization of the Qur'an, Ware points out that in West Africa, traditionally "Islamic knowledge was being transmitted as much through bodily practices as mere words" and that "just as the Prophet was the Walking Qur'an," "people were the books" and "Islamic knowledge was embodied knowledge." (p. 49) In my opinion, this resonates with the Muslims who have memorized Surah Yasin in South 
Sumatra. If it is learned by heart it means that it is readily available for recitation when needed.

\section{$5 \quad$ Signs of a Good Death}

When his father died, Ahmed was not with him. At the time he was living abroad. He received the news of his father's death only minutes afterwards. He had been sick, and although treatment had been sought, his condition had worsened. That was the reason why Ahmed had decided to return to Indonesia and to be at his father's side. However, his journey was not scheduled for another three days, and he missed his father's burial. Ahmed's main concern was to be certain that his father had died a good death. Although his older brother had described their father's last moments to him (which will be referred to later), he needed to know for sure. He asked his siblings to make a video call just before they closed the shroud over his father's face to see it one last time. According to Ahmed, it can be seen on the face of the dead person whether they have died a good death.

Ahmed was upset and tried to call his siblings several times. The internet connection was bad, and the family seemed intensely busy preparing the father's body for burial. However, Ahmed calculated the time and knew that they would soon proceed to the cemetery. Soon his chance of calming his heart concerning his father's spiritual condition at his death would be lost. He called his sister who told him that they were just about to pray over their dead father. According to Islamic law, an obligatory ritual prayer is conducted over the dead person (salat al-janazah). ${ }^{6}$ Ahmed waited and after a few minutes he called again. His sister told him that the body was already covered in the shroud and prepared to be carried to the cemetery. Ahmed felt very sad and called his brother insisting to see his father's face. His brother finally relented. He opened the green $\operatorname{cloth}^{7}$ of the coffin-like metal grid and uncovered their father's face. He put the camera of the phone very close so that Ahmed could see his father's face one last time. Upon seeing it he put his right hand to his chest and said: "Alhamdulilah." (gratitude be to God). I was sitting next to Ahmed and also watched the small phone screen that showed his father's white face. My fatherin-law must have had lost a lot of weight before his death. The whiteness of his

6 The Islamic funeral prayer is performed in congregation to seek pardon for the deceased and all dead Muslims. It is a collective obligation upon the Muslim community. The salat al-janazah is performed standing up only and does not include bowing and prostration.

7 The color green of the cloth that covers the metal grid is regarded to be an Islamic color by the people of South Sumatra as it was the Prophet Muhammad's favourite color. 
face made me later ask Ahmed whether they had put powder on his father's face, but my husband assured me that this was not the practice in Palembang.

Ahmed's ardent wish to see his father's face one last time and the pressure he put on his family to have his wish granted was born out of the need to becalm his own heart. He needed to reassure himself about his father's spiritual state right before his death. The moment he saw his father's face he felt calm: "I saw him smiling, and his face was so white and shining." For Ahmed, that was the sign that proved to him that his father had died a good death. The slight smile on his face and the shining whiteness of his skin. Both of these signs also moved Ahmed's youngest sister, Maryam, to withdraw her doa that she had initially made once she heard about her father's death (mentioned in the beginning of this article). There were other signs Ahmed gathered through the accounts of his siblings and uncle who had been present at his father's death that let him conclude that his father had died a good death.

While Ahmed's father was dying, his wife, his two children and his older brother were present and in the room together with him. Ahmed interpreted this as a good sign because his father spent his last moments the way he had spent his life: surrounded by his family. Ahmed's father asked those present to help him ("bantulah aku") by reciting istighfar (formula to repent to God) and the profession of faith (shahadah). The time shortly before a person passes on from this world is referred to as the agony of death. Al Ghazali describes the agony of death as something that if humans would know about it before, it would banish their heedlessness and their worldly distractions (translation by T.J. Winter, 2015: 37). It is the final phase before someone dies. This is a profoundly meaningful phase because it is during this phase that it is revealed to the dying person whether he/she died a good death or bad death. It is also during this phase that certain signs pointing to a good or bad death can be observed on the dying person (Abdul Karim, 2015). Especially reciting the shahadah to the dying person is commonly practiced by Muslims all over the world, as described above. In addition, Ahmed's mother recited Surah Yasin for her husband.

Reflecting on the time accompanying his father dying, Ahmed's older brother recalls that he observed and felt that his father was sweating during the last moments of his life. Without directly referencing al-Ghazali, Ahmed interpreted this sweating as a positive sign. Several weeks later when the family came together and the father's death became once again the central topic of conversation, Ahmed's elder sister recalled that she had offered water to her father to relieve the dryness of his lips. In the meantime, Ahmed had used the time and obtained an Indonesian translation of al-Ghazali's work on death and informed everybody that dry lips during the last moments of a person's 
life is indeed a good sign. This information pleased everybody. Several times Ahmed's mother related an observation she had made during the last days of her husband's life, which is the shortening of his tongue. When she noticed that his speech and especially his pronunciation become less clear, she asked him to stick out his tongue: "I knew that he will die because I saw that his tongue had become shorter [than usual]. And this is what I know from the people in my village."

When Ahmed's uncle noticed that his brother's tongue was not moving anymore, he asked for a mirror to be brought to confirm that his brother had stopped breathing and had passed on to the next world. Later Ahmed's uncle would tell us that he had held the mirror below his brother's nose, and when he had seen that the mirror was not steaming up, he had concluded that his brother had indeed passed away. This practice is worth noticing as it reveals that the ceasing of a person's breath is considered to be a safe sign that the soul (ruh) has left the body, and that the necessary preparations for the rituals after death need to commence. On later visits Ahmed's uncle would repeatedly say that he was very pleased with his brother's death, and that he wished for himself a death similar to his. He said:

I have witnessed many people die. For some it [the process of dying] is very difficult. Others just die in their sleep. They do not get a chance to do istighfar or recite the shahadah. But my brother's tongue was moving until his final breath reciting istighfar and the shahadah. It was truly a good death (benar-benar kematian yang baik). I pray every day that God grants me such a death. ${ }^{8}$

In the quote above, Ahmed's uncle hinted to the opposite of a good death, the bad or evil death (su-al-khatimah). For some it [the process of dying] is very difficult refers to people who experience extreme agony during their death. He explained that he witnessed this agony come in different forms. For some people, they experience tremendous pain, rattling sound can be heard from their throat and sometimes the saliva exists the mouth like foam (bui). These people, he explained, have usually difficulties reciting the shahada and according to him not being able to recite the shahada can be a sign of su-al-khatimah. ${ }^{9}$

8 Conversation at Ahmed's uncle's house in September 2019.

9 Imam al-Ghazali quotes the Prophet Muhammad explaining about the signs in a dying man: "[...] But if he should choke like a man being strangled, and if his colour should turn to red, and if he should foam at the mouth, then this is from the chastisement of God which has befallen him." (translation by T.J. Winter, 2015: 47-48). 
Suicide is also considered to be a su-al-khatimah, while death drowning or burning is usually viewed as a good death.

Immediately after Ahmed's father had died at 1opm, it was decided to transport his body to the small town he used to live in for most of his adult life. The organizing of the transport was carried out by Ahmed's oldest brother who, according to South-Sumatran tradition, became the head of the household following his father's death. According to Islamic teachings, one of the most important steps after the death of a person is washing (memandikan mayat) and shrouding the body for the burial. In Indonesia, it is customary to do this as quick as possible because the body usually begins to decay after 24 hours due to the tropical heat and high humidity. Ahmed's father's body was rushed to his hometown once his wife had decided to have him buried there. The washing of the body was done as a collective practice. Five members of the family kneeled on the floor and placed his body on their lap. In this way each of them could wash a part of the body. ${ }^{10}$ Later, Ahmed's sister told me that her father's body had felt very soft, and that it had been easy to move his body during the process of washing. She interpreted this as a good sign that her father had indeed died a good death. She further related to me that she had heard of other people's experiences in her home village and in Palembang where some dead were not easy to move and therefore not easy to wash.

After the shrouding was done, the body was placed on a plank with a metal scaffolding and covered with a green cloth. Flower garlands were placed above the green cloth before those present performed the funeral prayer over Ahmed's father. Then the body was brought to the local cemetery where the grave hole had already been dug. At 10am, Ahmed's father was buried and the grave closed. Taking into consideration that Ahmed's father had died in the provincial capital of Palembang, which is a six-hour car ride away from his

10 This traditional South Sumatran way of washing the dead collectively is rarely found nowadays. There are various reasons for this. The main reason is that the knowledge of washing the dead in the correct manner prescribed by Islamic law is no longer known to everybody. It usually needs a knowledgable person to instruct the members of a family to do the appropriate steps in the correct order. Also, family size decreases and family members often do not live in close proximity to each other anymore and are often not available for the washing. That is why the washing and shrouding of the body is usually done by a specialist of the community in a separate and especially allocated room in a mosque compound. 
home town, the whole process of transporting the dead body, washing, shrouding and burial, was a very smooth and quick affair. Several times, Ahmed's older brother told the events following his father's death to guests visiting the family and expressing their condolence. At every occasion he expressed his surprise at how smooth everything had gone and concluded that this was indeed a good sign and that his father had died a good death. The ritual of reading Surah Yasin for Ahmed's father started the same evening he was buried.

We traveled to the village on the third day after the death of my father-in-law. We arrived late at night but Ahmed's mother and siblings stayed up to welcome us. They were sitting in the living room, tired and motionless. I greeted my mother-in-law by taking her hand to my forehead (salim) and hugged my sisters-in-law who seemed unnaturally stiff. I said nothing because I tried to hide the tears welling up in my eyes. Nobody cried. Everybody seemed to be strangely removed. I had expected this absence of tears and strict control of emotions. This is the way I have come to know the people in South Sumatra and Central Java.. ${ }^{11}$ This cultural regulation of emotions ${ }^{12}$ like anger, sadness, and extreme happiness can be found in differing shades throughout the Indonesian archipelago (see Röttger-Rössler \& Markowitsch, 2009). ${ }^{13}$ It is not only in sad situations like the death of a family member that emotions are controlled and regulated, but emotions can be equally withheld during happy or joyous events like weddings.

During the next four days, we helped prepare and joined the nightly reading of Surah Yasin and supplications for my father-in-law. The family also provided food for the guests, which was given as charity (sedeqah) in the name of the deceased. It is believed that this charity will reach the deceased in form of

11 Clifford Geertz describes the funerals of the Javanese as "a calm, undemonstrative, almost languid letting go, a brief ritualized relinquishment of a relationship no longer possible" (Geertz 1960: 72). The proper emotional state to be achieved is called $i k h l a s$, a "willed affectlessness," an evenness of feelings from which the peaks of elation and the troughs of despair have been eliminated (Geertz 1960: 69-74, in: Metcalf \& Huntington, 1991: 60).

12 The phenomenon of cultural regulations of emotions describes the combined cultural processes that result in the alignment of emotions with cultural values, ideals, goals and concerns (De Leersnyder \& Boiger, 2013).

13 According to one of my interlocutors, Nani, a student of Javanese culture and Islamic spirituality, the controlling of emotions, positive as well as negative, is a tool to keep and protect a person's inner energy level. The more emotions are expressed, the more energy a person uses. Thus, the fewer emotions are expressed, the more energy can be preserved. 
light (cahaya) in the grave (membawa cahaya di kubur). There is a similar belief concerning the reading of Surah Yasin and supplications. They are supposed to bring light to the grave - something the dead can experience since, according to the Islamic worldview, they are thought to remain sentient in their grave. ${ }^{14}$

Reading Surah Yasin in communion in connection with a selamatan after a person's death is a Muslim tradition in South Sumatra, as it is in many other parts of Muslim Southeast Asia. It is also referred to as Yasinan. It is a time for the extended family, neighbors and friends to come together to support and console the grieving family. The practice of Yasinan is also closely connected to the localized Islamic concept of silaturahmi. ${ }^{15}$ It is considered as a quasi obligation to assist the grieving family due to the silaturahmi ties one shares with them as family, friend or neighbour. Yasinan is usually conducted at night after the night prayer (sholat isya). It is commonly conducted on the first, second, third and seventh night after a person has passed away. However, the practice of conducting Yasinan seven days in a row is also found in South Sumatra. Ahmed's mother decided to have a Yasinan every night after her husband had passed away, for seven consecutive days. However, on the third and seventh night more guests were invited to attend and more food was prepared to give as sedeqah to those attending. It is customary in South Sumatra that the grieving family is not only supported morally and spiritually in this difficult time, but family and neighbors join together to cook, clean and prepare everything for the Yasinan event at night. In addition, people bring gifts to the family in form of staple foods like sugar, cooking oil or rice, while others prefer to give life chicken or eggs. These gifts are usually used for preparing the selamatan that accompanies the Yasinan event, or they are used by the family in the following days and weeks. According to several women who were present during the preparation and cooking for the Yasinan, these gifts are supposed to relieve

14 Sending 'light' to the grave of the deceased is a practice also found in other religions and beliefs. For example, the Christian practice of placing candles on the grave, the place where a person died, or lightening a candle in the church in remembrance of the deceased is supposed to bestow light to the person in the grave.

15 Silaturahmi is a concept based on what God and the Prophet Muhammad said about keeping or mending ties between family or kin. Several verses in the Qur'an can be used to explain the concept of silaturahmi. I use the following definition of silaturahmi in the Indonesian context: Silaturahmi is a religiously motivated form of social interaction (practice) through which consciously or unconsciously translocal relations are maintained on various scales from the local to the global and on different societal levels, including kinship, educational, economic and religious connections. Silaturahmi is also an intention (niat) that can serve as a religious motivator, as well as a reminder, and is mostly, although not exclusively, practiced by Indonesian Muslims (Seise, 2017; 2021). 
the family's burden to feed all the guests and to give some form of financial aid for the weeks to come.

The constant flow of guests is supposed to entertain the grieving family, and most importantly the wife of the deceased. Several times I was surprised at the fact that the women present intentionally told amusing stories and did not suppress their laughter and joy. ${ }^{16}$ However, this fact can be related to the traditional Islamic worldview and the perception of dying a good death. As described above, death is not considered the end of our existence but rather the end of this life's test and a transitional stage for the soul. The spiritual being that everyone alive essentially is has to leave this world eventually and reach the final destination. If signs of a good death have been observed in a dying person, then the hope that the final destination of this soul is a good one (meaning paradise or jannah) certainly helps the people left behind to deal with their grief. The signs observed in a dying person that might point to a good death, or remembering the good deeds and the pious life style of a person, can create hope and positivity for the future. Additionally, as remarked by Samuels (2019), "the active cultivation of acceptance" (p.91) and the notion of pasrah (surrendering what happened to God) (ibid: 92) are essential parts of dealing with grief that I could also observe. What Samuels' informant described as pasrah is similar to what Maryam described as being pleased (ikhlas) with her father's death. However, to my understanding pasrah has a slightly negative connotation of not having another choice than acceptance while $i k h l a s$ is more positive in the sense that it embodies an active choice to accept God's will.

The 4oth day after the death of a person is seen as an extremely important day to commemorate. It is on this evening that the whole family gathers again to engage in a Yasinan ritual. One important element of the ritual of remembering the 4oth death day is the giving away of a small Yasin booklet on behalf of the deceased. This is a practice observed all over Indonesia and in other parts of the Muslim world, for example in Malaysia, Turkey and India. It is in fact a small industry that is especially focused on providing custom made Yasin booklets with the name of the deceased, a picture and the names of close

16 This is in contrast to my personal experience growing up in Germany where people are very hesitant to visit a grieving family or person because they do not want to disturb their grieving process. To hear laughter or see joy in a grieving household just several days after the death of a person is unimaginable. 
family members left behind. These Yasin booklets come in different formats, layouts and, of course, price range. Ahmed's family also followed this practice of ordering custom-made Yasin booklets for their late father and gave them away as gifts to close relatives, neighbours and friends. The idea behind this practice is that it is a form of continuous charity (sedeqah jariyah) on behalf of the deceased. In the very front of the booklet, one can find the request for forgiveness for the deceased if he/she wronged the reader in his/her lifetime, followed by a request for supplication for the deceased. There is the belief and hope that the very act of a person reading from this Yasin booklet that was given on behalf of the deceased will be counted as a good deed for the latter (besides being a good deed for the reader herself). Ahmed's family provided one hundred Yasin booklets, and it were these new booklets that were used by the guests during the reading of Surah Yasin during the ritual of remembering the 4oth death day. Although some guests had brought their own booklets with them, I observed that they used the new booklet given to them instead. This shows the importance of honoring the grieving family and their wish to bestow additional good deeds on the deceased..$^{17}$ In general, doa (supplication) for the deceased is an ongoing practice by most close family members and basically after every obligatory prayer Ahmed, his mother and siblings supplicate to God for the father. There are different doa from the Prophet Muhammad mentioned in hadith for this purpose. In addition, personalized supplications in the local language can be used. ${ }^{18}$

\section{Negotiating the Traditional Islamic Rituals of Yasinan}

During the ten days of conducting Yasinan, one neighboring family, the Helandris, totally refrained from attending the traditional ritual. I argue that their non-affiliation with the traditional rituals points to the fact that they are not part of the traditional South Sumatran religioscape described above. In fact, they are part of a different religioscape, which exists simultanously, and that is characterized by different parameters of which some will be mentioned below. By telling and analyzing the family's reasons not to attend the Yasinan, I aim to show that the perception of a good death and especially the postmortem signs related to local Islamic rituals form a contested issue. Death

\footnotetext{
17 Visiting the grave of a deceased (ziarah kubur) constitutes an additional important ritual after the passing of a person, which unfortunately cannot be elaborated on in more detail here.

18 For the importance of doa in the process of grieving see Samuels (2019: 94-96).
} 
and the rituals connected to it are used to negotiate who is Islamically right or wrong. This is so because the very rituals involved are contested among some members of the community, which is not a new issue in Indonesia. It reflects the ongoing debate of what, to condense it in a simple way, is local and global in Islam in Indonesia and how the supposedly correct understanding of Islam is negotiated (e.g. Redfield 1956; Geertz 196o, 1968; Woodward 1989; Bowen 1993; van Bruinessen 1999; Joll 2012). In this, we can observe the historically grown discourse that Islam in Southeast Asia is seen as qualitatively different and in this respect "less" Islamic than the Islam found in the Arabic speaking world due to "ahistorical and essentialised understandings of 'Islam' conceptualised in relation to a rather limited range of modern reformist conceptions that persist across various academic fields, as well as in popular perceptions" (Feener 2010: 470). It is these modern reformist conceptions that make up the religioscape which the Helandris are part of. What I found especially startling in my case study is the fact that disagreeing with a certain Islamic ritual can lead in fact to a condemnation of the deceased and a reversal of traditionally perceived categories of a good and bad death.

According to South Sumatran tradition and the understanding of Ahmed's family, the two families had considered each other as semi-related, ever since Ahmed's father had built the Helandris' house, a huge wooden structure in the traditional South Sumatran style. A few years ago, the Helandri family had joined a group of what is locally referred to as Wahhabi Muslims. This group opposes all forms of traditional, localized Islamic practices such as Yasinan which, according to their point of view, are not rooted firmly in the Sunnah of the Prophet Muhammad and are therefore considered as a deviant or unlawful innovation (bid'ah sayyiah)..$^{19}$ The group has established their own mosque where they do not engage in the traditional practice of communal supplication after prayer and omit the qunut prayer, a special supplication during the ritual morning prayer that is commonly recited by Muslims following the Shafi $i$ school of law. ${ }^{20}$ They do not accept invitations for Yasinan. Therefore, I argue

19 For a general overview on the history of the Wahhabis and their mission: The Wahhabi Mission and Saudi Arabia by David Commins (2006). In anti-Wahhabi circles since the 18th century, the following critique has been put forward: the Wahhabis interpret the Qur'an according to personal opinion, they disrespect the Prophet, they do not respect the views of authoritative 'ulama, and they consider everybody since the 13th century to be infidels, except those who agree with them (Commins, 2006: 136).

These ritual practices are usually attributed to the ahl al-sunnah wa'-jamaiah (in Indonesian abbreviated as ASWAJA). It is an essential term in the broader Islamic discourse, and serves as a mode of identification with the supposedly correct way of practicing Islam. It is a contested term as it is often used to legitimize and reinforce a certain mode of practicing Islam. Furthermore, within the inner Islamic debates in Indonesia, 
that they have established their own religioscape within the traditional religioscape of South Sumatra. Rejecting an invitation is a social affront in South Sumatra and it is good etiquette ( $a d a b)$ to send at least one family member if one is invited for a wedding, Yasinan or any other kind of religious feast. ${ }^{21}$

Opposing the traditionally established ritual of Yasinan in South Sumatra illustrates an ongoing debate about different Islamic rituals between the biggest Muslim organization Nahdlatul Ulama, representing what is referred to as traditional Islam and ahl al-sunnah wa'-jama'ah on the one hand, and a reformist understanding from different spectrums, including the Muhammadiyah, Wahhabism and Salafism (Ali 2011). These include customs and traditions surrounding death like slametan (ritual feast), tahlilan (ritual remembrance of a person's death that includes reading Qur'an and supplications for the deceased) and talqin (recitations for the deceased before burial). In his book Muslims through Discourse (1993), Bowen observed similar negotiations about rituals surrounding death. The difference of opinion were also rooted in the binary of so called traditional and modern reformist interpretations of Islam (p.251-264).

When we visited the Helandri family after the seven days of Yasinan, we were welcomed and served drinks and snacks. Ahmed was of the opinion that the practice of silaturahmi with the Helandri family needed to be preserved, despite the fact that they had not joined any of the Yasinan for his father. He understood their reason, but that it was essential to keep good and friendly ties despite their difference of opinion. ${ }^{22}$ Upon our arrival, I noticed that the father of the Helandri family felt a bit uneasy and shortly after we arrived, he started to seemingly defend himself and explain why he had not attended the Yasinan for Ahmed's father:

competing definitions exist. For the Indonesian context, a broad definition of ASWAJA was given at the NU Bahsul Masail in 2002. To AswaJA belong those Muslims who consistently and firmly adhere to the Sunnah of the Prophet and the way of life of the companions in the fields of doctrine, practice and ethics (Laffan, 2005). For a more detailed discussion see Seise (2017).

21 From an Islamic perspective, the importance of accepting an invitation in South Sumatra can also be found in a hadith narrated by Abu Hurayrah: I heard Allah's Apostle saying, "The rights of a Muslim on the Muslims are to follow the funeral processions, to accept invitation and to reply the sneezer" (Sahih Bukhari, Vol 2, Book 23, Number 332).

22 This stance is reflective of the Indonesian national motto 'Unity in Diversity' (Bhinekka Tunggal Ika), the driving concept to keep the country with its diverse people, religions and cultures relatively peaceful and unified. It is based upon the official, foundational philosophical theory of Indonesia Pancasila and is taught to Indonesian school children. 
I am sorry I could not attend the last seven nights. It does not mean I did not respect your father. You know I respect him very much. Our families are like one family (Ahmad nodded his head affirmingly). It is just that there are religious issues where we cannot make a compromise (tidak boleh berkomprimi). I did see your mother, though, to express my condolences.

Ahmed did not argue with the Helandri father over their different religious convictions concerning Yasinan. However, later he expressed his sorrow (saya merasa kasihan) about the Helandris' decision to socially and religiously isolate themselves.

In my point of view, the debate about the Yasinan ritual after a person's death has the potential to lead to a debate about the perception of a good death itself. If the Yasinan ritual is perceived as an unlawful innovation, as in the opinion of the Helandri family, what is traditionally perceived as a sign of a good death in South Sumatra seems to be questioned. And where traditionally there is consent in the signs of a good death, disagreement evolves. This development speaks back to the very nature of Islamic reformist groups like the Wahhabis, who are critical about traditional Islamic practices in Indonesia and tend to engage in excessive vilification (takfir $)^{23}$ (Sirriyeh, 1989). Furthermore, the contested ritual of Yasinan in a small town in South Sumatra is an example of the fact that a certain religioscape of a place is in constant motion and never static. Different external influences in the form of Islamic interpretations and practices enter established religioscapes and challenge traditionally established ways of practicing Islam, while also having the potential to challenge and disturb social and religious harmony in a community.

With the example of a case study from the religioscape of South Sumatra, I tried to provide an insight into the traditional Islamic worldview of a South Sumatran family regarding death and what it means to die a good death. Islam is a religion that teaches that an individual's ultimate goal in life is to die a death that signals God is pleased with one's life. The parameters of what a good death means are set by Islamic teachings. Several signs of a good death have been discussed by classical Muslim scholars such as al-Ghazali. Other signs mentioned in this article reflect cultural norms and priorities, for example the importance

23 A concept denoting excommunication, as one Muslim declaring another Muslim as a non-believer, kafir, or apostate. 
of family and communal ties. In addition, some of the signs mentioned above also reflect what individuals wish for themselves such as dying in the company of their loved ones as opposed to dying alone. The discussion about negotiating traditional Islamic rituals has revealed that negotiations about correct versus incorrect Islamic practices do not stop before reverent topics like death. Rather, they have the potential to lead to a serious divide in the community, especially when the discussion is about the end of life of a respected and cherished member. The establishment of a new religioscape influenced by different parameters is the consequence of such negotiations and disputes. In a follow-up study it would be interesting to compare Muslim perceptions of a good death from different parts of the Muslim world. Unfortunately, the traditional ritual of visiting the grave of the deceased could not be further discussed in this article. The debate about a good and bad death within the Islamic context and the reading of divine signs also points to the discussion and scholarship of destiny and the course a person's life had taken. This interesting point requires further research as well.

\section{Bibliography}

Abdul Karim. (2015). Makna Kematian Dalam Perspektif Tasawuf. Esoterik, 1(1), 21-46. Abdul Manan. (2015). The Ritual Calendar of SouthAcèh, Indonesia (Vol. 22). Verlagshaus Monsenstein und Vannerdat OHG Münster.

Abdul Manan, \& Arifin, M. (2019). Cultural Traditions in Death Rituals within the Community of Pidie, Aceh, Indonesia. Miqot: Jurnal Ilmu-Ilmu Keislaman, 43(1), 130-144.

Adams, K. M. (n.d.). Club Dead, Not Club Med: Staging Death in Contemporary Tana Toraja (Indonesia). Southeast Asian Journal of Social Science (Now Asian Journal of Social Science), 21(2), 62-72.

Adams, K. M. (1993). The Discourse of Souls in Tana Toraja (Indonesia): Indigenous Notions and Christian Conceptions. Ethnology, 32(1), 55-68.

Alatas, I. F. (2008). Securing Their Place: The Ba'alawi, Prophetic Piety \& Islamic Resurgence in Indonesia. National University of Singapore.

Alatas, I. F. (2014). Pilgrimage and Network Formation in Two Contemporary Ba 'Alawi Hawl in Central Java. Journal of Islamic Studies, 25(3), 1-27.

Alatas, I. F. (2016). The Poetics of Pilgrimage: Assembling Contemporary Indonesian Pilgrimage to Ha dramawt, Yemen. Comparative Studies in Society and History, $58(3)$, $607-635$.

Al-Ghazali, I. (2015). The Remembrance of Death and the Afterlife. BookXL of the Revival of the Religious Sciences. (T. J. Winter, Trans.; 2nd ed.). The Islamic Text Society. 
Ali, M. (2011). Muslim diversity: Islam and local tradition in Java and Sulawesi, Indonesia. Indonesian Journal of Islam and Muslim Societies, 1(1), 1-35.

Ali, Md. Y. (2017). The Islamic Worldview: Selected Essays. The International Institute of Islamic Thought (IIIT E\&SEA) \& International Islamic University Malaysia (IIUM). Azra, A. (2004). The Origins of Islamic Reformism in Southeast Asia Networks of Malay-Indonesian and Middle Eastern 'Ulamä' in the Seventeenth and Eighteenth Centuries. Asian Studies Assoc. of Aus tralia in assoc. with Allen \& Unwin.

Baumann, B., Kretschmer, D., von Plato, J., Pomerance, J., \& Rössig, T. (2020). "Small Places, Large Issu es" Revisited: Reflections on an Ethnographically Founded Vision of New Area Studies. International Quarterly for Asian Studies, 51(3-4 Online First), 1-33.

Bowen, John R. 1993. Muslims Through Discourse: Religion and Ritual in Gayo Society. Princeton NJ: Princeton University Press.

Bruinessen van, M. (1990). Kitab Kuning: Books in Arabic Script Used in the Pesantren Milieu: Comments on a New Collection in the Kitlv Library. Bijdragen Tot de Taal-, Land-En Volkenkunde, 146(2/3), 226-269.

Bruinessen van, Martin. 1999. "Global and Local in Indonesian Islam." Kyoto 37 (2): 46-63.

Choong, K. A. 2015. “Islam and Palliative Care." Global Bioethics 26 (1): 28-42.

Clarke, A. E. (2005). Situational Analysis in Practice: Mapping Research with Grounded Theory. SAGE Pu blishing.

Commins, D. (2006). The Wahhabi Mission and Saudi Arabia. I.B. Tauris.

De Leersnyder, J., Boiger, M., \& Mesquita, B. (2013). Cultural regulation of emotion: Individual, relational, and structural sources. Frontiers in Psychology, 4(Article 55), 1-11.

Feener, Michael R. 2010. "South-East Asian Localisations of Islam and Participation within a Global Umma, c. 1500-180o." In The New Cambridge History of Islam, edited by David O. Morgan and Anthony Reid, 470-503. Cambridge University Press.

Geertz, Clifford. 196o. The Religion of Java. Chicago: University of Chicago Press.

Geertz, Clifford. 1968. Islam Observed. New Haven: Yale University Press.

Grillo, L. S. (n.d.). Rambu Solo': The Toraja Cult of the Dead and Embodied Imagination. 1-36. Retrieved August 9, 2021, from https://www.academia.edu/21307134/ Rambu_Solo_the_Toraja_Cult_of_the_Dead_and_Embodied_Imagination.

Hefner, R. W. (1985). Hindu Javanese: Tengger Tradition and Islam. Princeton University Press.

Joll, Christopher M. 2012. "Local and Global Islams in Southeast Asia: Historical and Anthropological Per spectives." In Social Science and Knowledge in a Globalising World, edited by Z. Ibrahim, 219-42. Petaling Jaya: Pssm/sindc.

Laffan, M. (2005). The Fatwā Debated? Shūrā in One Indonesian Context. Islamic Law and Society, 12(1), 93-121. 
Laffan, M. (2011). The Makings of Indonesian Islam: Orientalism and the Narration of a Sufi Past. Princton University Press.

Metcalf, P., \& Huntington, R. (1991a). Celebrations of Death: The Anthropology of Mortuary Ritual (2nd ed.). Cambridge University Press; Cambridge Core.

Metcalf, P., \& Huntington, R. (1991d). Emotional Reactions to Death. In Celebrations of Death: The Anthropology of Mortuary Ritual (2nd ed., pp. 43-61). Cambridge University Press.

Moris, Megawati. 2016. Al-Ghazali's Influence on Malay Thinkers. Kuala Lumpur, Malaysia: Islamic and Strategic Studies Institute (ISS I) Malaysia.

Nasir, M. A. (n.d.). Revisiting the Javanese Muslim Slametan: Islam, Local Tradition, Honor and Symbolic Communication. Al-Jāmiah: Journal of Islamic Studies, $57(2$ (2019)), 329-358.

Nasr, S. H. (2015). The Study Quran: A New Translation and Commentary. Harper One.

Rajendra, A., \& Temple, N. (2016). Religious Ceremonies in Balinese Society: A Case Study of a Cremation Ritual in Tabanan. International Journal of Indonesian Studies. http://eprints.hud.ac.uk/id/eprint/29104/ (accessed 22.12.2020).

Redfield, Robert. 1956. Peasant Society and Culture. Chicago: University of Chicago Press.

Ricklefs, M. C. (2006). Mystic Synthesis in Java: A History of Islamization from the Fourteenth to the Early Nineteenth Centuries. East Bridge.

Röttger-Rössler, B., \& Markowitsch, H. J. (Eds.). (20o9). Emotions as Bio-cultural Processes. Springer.

Samuels, Annemarie. 2019. After the Tsunami. University of Hawaii Press.

Schmitt, A., Déderix, S., \& Crevecoeur, I. (2018). Gathered in Death Archaeological and Ethnological Per-spectives on Collective Burial and Social Organisation. Presses universitaires de Louvain.

Schröter, S. (1998). Death Rituals of the Ngada in Central Flores, Indonesia. Anthropos, 93, 417-435.

Seise, C. (2017). Religioscapes in Muslim Indonesia: Personalities, Institutions and Practices. regiospectra.

Seise, C. (2019). The Muslim Researcher: Reflections on Insider/Outsider Research in Indonesia. Journal of Islam in Asia, 16(1), 297-324.

Sirriyah, E. (1989). Wahhabis, Unbelievers and the Problems of Exclusivism. Bulletin (British Society for Middle Eastern Studies), 16(2), 123-132.

Slama, M. (2012). "Coming Down to the Shop": Trajectories of Hadhrami Women into Indonesian Public Realms. The Asia Pacific Journal of Anthropology, 13(4), 313-333.

Ware III, R. T. (2014). The Walking Qur'an: Islamic Education, Embodied Knowledge and History in West Africa. The University of North Carolina Press.

Woodward, Mark. 1989. Islam in Java: Normative Piety and Mysticism in the Sultanate of Yogyakarta. Tucson: The University of Arizona Press. 
Woodward, Mark. 2011. "The Slametan: Textual Knowledge and Ritual Performance in Yogyakarta." In Ava, Indonesia and Islam. Muslims in Global Societies Series 3. Dordrecht: Springer.

Woodward, M. (n.d.). Islam in Java: Normative Piety and Mysticism in the Sultanate of Yogyakarta. The University of Arizona Press.

Yusof @ Salleh, Y. M., \& Ramli, A. M. (2019). Local Wisdom in Agony of Death among Malay-Muslim Society in Malaysia. International Journal of Academic Research in Business \& Social Sciences, 9(9), 426-436. 